\title{
Discourse and Pragmatics
}

Ribut Wahyudi, UIN M2I Malang

March 4, 2013.

Email: ribut@bsi.uin-malang.ac.id 


\section{What is pragmatics?}

- Pragmatic is 'the study of meaning in relation to the context in which a person is speaking or writing'.

- Co-operative principle

- Cross-cultural pragmatics

- The relationship between linguistic form and communicative function is of central interest to Pragmatic (Paltridge, 2006,p. 53) 


\section{Language, context and discourse}

- The role of context situation: physical context, the social context, the mental worlds and the role of people in the interaction. e.g. two people's talk in the restaurant

- A number of key aspects: situational context, background knowledge context, co-textual context, discourse community. 


\section{Speech act and discourse}

- Austin (1962) How to things with words

- Searle (1969) Speech Act

- Austin \& Searle = language is used to do 'things' other than just true or false statement

- They argue that we perform physical acts, we also perform acts by using language. 


\section{Conts...}

That is we use language to give orders, to make requests, to give warning or advice, $=>$ to do 'things' that go beyond the literal eaning.

- Proportional content, illocutionary force.

Austin = locutionary act, illocutionary act, and perlocutionary act e.g. Bus driver:

This bus won't move until you boys move of the doorway

y 


\section{Direct and Indirect speech act}

Direct speech act: the utterance means exactly what one says

Indirect speech act: speaker's intention is

sth quite different from the literal meaning. this room's a real mess 


\section{Felicity conditions and discourse}

Felicity conditions $=$ a required number of conditions for speech act to work

Austin argues that felicity conditions must

be carried out correctly and completely

ecessary terms: felicitous, misfire,

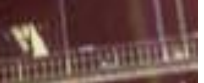




\section{Rules versus principles}

Searle argues that felicity conditions are 'constitutive rules'=>pragmatic use of language is rule governed.

omas (1995) prefers "principles" against 'constitutive rule'.

Thomas argues: rules = all or nothing, yes or po. clearly, one rule precludes another rule, exclusive, definite while principle $=$ more or less, partially, fairly clearly, co-occur, probabilistic. 


\section{Presupposition and discourse}

Presupposition $=$ common ground that is assumed to exist between language users.

Two kinds of presupposition: conventional (grammar) and pragmatic presupposition context).e.g.

CP: would you like some coffee?

PP see. p.61. 


\section{The Cooperative and discourse}

Grice (1975) 'Logic and conversation'.

Four maxims: quality, quantity, relation (relevant) and manner.

Unsure? Use metadiscourse (Hyland, 05b) e.g. 'I may be mistaken, but...',

may be' 


\section{Flouting the cooperative principles}

See page.64.

e.g. student and librarian

e.g. Chinese and American student

the speakers purposely do not adhere the naxims due to certain conditions. 


\section{Flouting vs violating maxims}

Flouting $=$ the speaker does not observe a maxim but has no intention of deceiving or misleading the other person.

iolating $=$ there is a likelihood that a speaker is liable to mislead the other serson.

infringe maxim'?=> linguistic capacity

bot-out maxim'? => breaches a dentiality agreement 


\section{Overlap between maxims}

an utterance may be both unclear and longwinded, flouting the maxims of quality and quantity at the same time (Cutting, $02)$ e.g. the thief of an eyeliner in courtroom interaction. 


\section{Cross-cultural pragmatic and discourse}

Communication across cultures.

e.g. Beal (1992) How are you? Between Australian and French.

e.g. Austin (1998) Letters of commendation in academic setting (in English and in Japanese) 


\section{Cross-cultural pragmatics}

"studies which investigate the cross cultural use of speech act".

e.g. "thanks" in English = we feel sth good toward them because of sth good they have done and we want them to be good in return. "sorry" in Japanese means "thank you". Thanking = 'a debt not yet paid calls for an apology from the debtor'. Apology = one way of expressing indebtedness, and thanking someone. (Cameron, 2001; Wierzbicka, 2003). 


\section{Conts...}

Pragmalinguistic and sociopragmatic (Leech, 1983)

Cross-cultural pragmatic failure (Thomas,1983): ciopragmatic and pragmalinguistic failure.

- e.g. Sociopragmatic failure: a foreign manager critizing a Thai worker in front of their colleagues - g. Pragmalinguistic failure: 'I killed my son, it is hy fault', a Korean immigrant was sentenced 20 h prison in US.

y. 


\section{Conversational implicature and discourse}

'There's nothing on at the movies'

Implicature vs inference

a maxim might be flouted because of a clash with another maxim (see p.70-71). 


\section{Conventional and particularized conversational implicatures}

conventional implicatures: e.g. anyway, but, on the other hand, yet,etc particularized conversational implicature:

g. A: You're out of coffee B: Don't worry there's a shop on the corner

Scalar implicature: expressions of scale of values e.g. all, most, something, nothing. 


\section{Politeness, face and discourse}

Lakoff (1973) three maxims of politeness: 'don't impose', 'give options', and ' make your hearer feel good'

E.g. see page 72-73.

Involvement and independence in spoken

and written discourse.

choosing a politeness strategy 


\section{Face and Politeness across cultures}

Gu (1990) Politeness in Chinese is not psychological want but rather social norms. Face is threatened when one fails live up social standards.

apanese politeness is less strategic and more a matter of socially obligatory inguistic choices through which social harmony is achieved (Eelen, 2001).

A 


\section{conts..}

Gift-giving rituals $=$ a positive politeness strategy in English or involvement strategy

Japanese indirectness is a sign of

intimacy

p.75. 


\section{Politeness and gender}

'Hello gorgous' = cab be positive and negative

Politic verbal behaviour (Watt, 2003). The sults, critiques etc are the discourse expectations of a good parliamentary speaker regardless of gender (in UK context)

So? Politeness and gender vary across context y 
FTA, Politeness and Cross-cultural

\section{Pragmatic Failure}

fta: see.student librarian

Mitigation devices (Fraser, 1980)

Off record speech act.

g. A: I'm dying for a drink

B: Yes, it's really hot isn't it?

Politeness $=$ varies across cultures

A lack of understanding of politeness strategies

in different languages and cultures $=>$ cross

ultural pragmatic failure. 


\section{Conts...}

Politeness: culture and language specific. Pragmatic competence of $L 2$ speakers are crucial parts of discourse and communicative competence (Kasper, स्वात्रा997). 


\section{Data Analysis Project: page 80-81.}

Do no 1 up to no.4

Each number: 300 - 400 words.

Use references: more than three

Using APA style

Make sure to have "voice" in your writing.

Next Week's Meeting. 


\section{Notes on Project}

Use one/two/three/four texts for your analysis no. 1 up to no.4., if you think that 1 text is enough/appropriate to do four mbers then it is ok just to have one. BUT. If one text is not appropriate for four erfferent analyses, then use more texts, may be four. 
Reference

Paltridge, B. (2006). Discourse

Analysis. London: Continuum.

\section{Kingsoft Office}

Make Presentation much mose fun 